\title{
Microscopic Evaluation of 3D-Printed Materials Surface and Characteristic Microstructure
}

\section{Michaela Fousová, Dalibor Vojtěch, Jaroslav Fojt}

Department of Metals and Corrosion Engineering, Faculty of Chemical Technology, University of Chemistry and Technology Prague, 16628 Prague 6. Czech Republic. E-mail: fousovam@vscht.cz, dalibor.vojtech@vscht.cz, fojtj@vscht.cz

Selective laser melting (SLM) is one of additive manufacturing technologies capable of processing metallic materials. The quality of final product is influenced by a variety of parameters. Although this technology has been studied intensively for several years, the optimal setting is still in search as these parameters vary with different materials, different designs and alike. The layer-by-layer manufacturing approach brings about several characteristic features. Therefore, this study is focused on observation of characteristic microstructure evolution, resulting surface morphology and changes in surface chemistry when SLM is applied in processing of titanium alloy Ti-6AI4V and AISI 316L stainless steel. As these materials represent most widely used implantable biomaterials, their surface properties are of particular importance.

Keywords: 3D printing, SLM, AISI 316 L, Ti-6Al-4V, surface evaluation

\section{Acknowledgement}

Authors wish to thank the Czech Science Foundation (project no. P108/12/G043) and specific university research (MSMT No 20-SVV/2016) for the financial support of this research. Thanks also to Ing. Čjka and his company for the preparation of tested material.

\section{References}

[1] SUN, Z., ET AL. (2016). Selective laser melting of stainless steel 316L with low porosity and high build rates. In: Materials \& Design, Vol. 104, pp. 197-204. Elsevier Ltd.

[2] FRAZIER, W. E. (2014). Metal Additive Manufacturing: A Review. In: Journal of Materials Engineering and Performance, Vol. 23, No. 6, pp. 1917-1928. Springer US.

[3] ZHAI, Y., GALARRAGA, H., LADOS, D. A. Microstructure, static properties, and fatigue crack growth mechanisms in Ti-6Al-4V fabricated by additive manufacturing: LENS and EBM. In: Engineering Failure Analysis. Elsevier Ltd. In press. DOI: http://dx.doi.org/10.1016/j.engfailanal.2016.05.036

[4] MURR, L. E., ET AL. (2012). Metal Fabrication by Additive Manufacturing Using Laser and Electron Beam Melting Technologies. In: Journal of Materials Science \& Technology, Vol. 28, No. 1, pp. 1-14. Elsevier Ltd.

[5] MERTENS, A., ET AL. (2014). Mechanical properties of alloy Ti-6Al-4V and of stainless steel 316L processed by selective laser melting: influence of out-of-equilibrium microstructures. In: Powder Metallurgy, Vol. 57, No. 3, pp. 184-189. Maney Publishing.

[6] FOUSOVÁ, M., ET AL. (2015). 3D Printing as an Alternative to Casting, Forging and Machining Technologies? In: Manufacturing Technology, Vol. 15, No. 5, pp. 809-814. Czech Republic.

[7] THIJS, L., et al. (2010). A study of the microstructural evolution during selective laser melting of Ti-6Al-4V. In: Acta Materialia, Vol. 58, No. 9, pp. 3303-3312. Publisher, Place Published.

[8] KUČEROVÁ, L., ZETKOVÁ, I. (2016). Metallography of 3D printed 1.2709 tool steel. In: Manufacturing Technology, Vol. 16, No. 1, pp. 140-144. Czech Republic.

[9] KASPEROVICH, G., ET AL. (2016). Correlation between porosity and processing parameters in TiAl6V4 produced by selective laser melting. In: Materials \& Design, Vol. 105, No., pp. 160-170. Elsevier Ltd.

[10] VAITHILINGAM, J., ET AL. (2016). Surface chemistry of Ti6Al4V components fabricated using selective laser melting for biomedical applications. In: Materials Science and Engineering: C, Vol. 67, pp. 294-303. Elsevier B.V.

[11] LIU, Y. J., ET AL. (2016). Microstructure, defects and mechanical behavior of beta-type titanium porous structures manufactured by electron beam melting and selective laser melting. In: Acta Materialia, Vol. 113, pp. 56-67. Elsevier Ltd.

[12] CHEN, Q., THOUAS, G. A. (2015). Metallic implant biomaterials. In: Materials Science and Engineering: R: Reports, Vol. 87, pp. 1-57. Elsevier B.V. 
[13] CASATI, R., LEMKE, J., VEDANI, M. (2016). Microstructure and Fracture Behavior of 316L Austenitic Stainless Steel Produced by Selective Laser Melting. In: Journal of Materials Science \& Technology, Vol. 32, No. 8, pp. 738-744. Elsevier Limited.

[14] YAN, C., ET AL. (2012). Evaluations of cellular lattice structures manufactured using selective laser melting. In: International Journal of Machine Tools and Manufacture, Vol. 62, pp. 32-38. Elsevier Ltd.

[15] VAN BAEL, S., ET AL. (2011). Micro-CT-based improvement of geometrical and mechanical controllability of selective laser melted Ti6Al4V porous structures. In: Materials Science and Engineering: A, Vol. 528, No. 24, pp. 7423-7431. Elsevier B.V.

[16] YAN, C., ET AL. (2015). Ti-6Al-4V triply periodic minimal surface structures for bone implants fabricated via selective laser melting. In: Journal of the Mechanical Behavior of Biomedical Materials, Vol. 51, pp. 61-73. Elsevier Ltd.

[17] HRABE, N. W., et al. (2011). Compression-compression fatigue of selective electron beam melted cellular titanium (Ti-6Al-4V). In: Journal of Biomedical Materials Research - Part B Applied Biomaterials, Vol. 99 B, No. 2, pp. 313-320. Wiley Periodicals, Inc.

[18] SALLICA-LEVA, E., JARDINI, A. L., FOGAGNOLO, J. B. (2013). Microstructure and mechanical behavior of porous Ti-6Al-4V parts obtained by selective laser melting. In: Journal of the Mechanical Behavior of Biomedical Materials, Vol. 26, No., pp. 98-108. Elsevier Ltd.

[19] BAČA, A., ET AL. (2015). Effect of Surface Roughness on the Fatigue Life of Laser Additive Manufactured Ti6Al4V Alloy. In: Manufacturing Technology, Vol. 15, No. 4, pp. 498-502. Czech Republic.

[20] ČAPEK, J., ET AL. (2016). Highly porous, low elastic modulus 316L stainless steel scaffold prepared by selective laser melting. In: Materials Science and Engineering: C, Vol. 69, pp. 631-639. Elsevier B.V.

[21] VILARO, T., COLIN, C., BARTOUT, J. D. (2011). As-Fabricated and Heat-Treated Microstructures of the Ti6Al-4V Alloy Processed by Selective Laser Melting. In: Metallurgical and Materials Transactions A, Vol. 42, No. 10, pp. 3190-3199. Minerals, Metals and Materials Society; ASM International.

[22] ATTAR, H., ET AL. (2014). Manufacture by selective laser melting and mechanical behavior of commercially pure titanium. In: Materials Science and Engineering: A, Vol. 593, No., pp. 170-177. Elsevier B.V.

[23] KRUTH, J. P., ET AL. (2003). Lasers and materials in selective laser sintering. In: Assembly Automation, Vol. 23, No. 4, pp. 357-371. MCB UP Ltd.

[24] GONG, H., ET AL. (2015). Influence of defects on mechanical properties of Ti-6Al-4 V components produced by selective laser melting and electron beam melting. In: Materials \& Design, Vol. 86, pp. 545-554. Elsevier Ltd.

[25] FOUSOVÁ, M., VOJTĚCH, D., KUBÁSEK, J. (2016). Titanium alloy Ti-6Al-4V prepared by Selective Laser Melting (SLM). In: Manufacturing Technology, Vol. 16, No. 4, pp. 691-697. Czech Republic.

[26] CHERRY, J. A., ET AL. (2015). Investigation into the effect of process parameters on microstructural and physical properties of 316L stainless steel parts by selective laser melting. In: The International Journal of Advanced Manufacturing Technology, Vol. 76, No. 5, pp. 869-879. Springer International Publishing, London. 